Marta Musiał*

\title{
ZASTOSOWANIE INSTRUMENTÓW ZARZĄDZANIA FINANSAMI OSOBISTYMI W POLSKICH GOSPODARSTWACH DOMOWYCH'
}

\section{Wprowadzenie}

Jednym z ważnych elementów zarządzania finansami osobistymi jest gromadzenie danych potrzebnych do przeanalizowania sytuacji finansowej gospodarstwa domowego. Podstawowy zakres informacji powinien obejmować m.in.: spis majątku, rachunki bieżące i oszczędnościowe, rachunki walutowe, certyfikaty depozytowe, akcje, obligacje, fundusze inwestycyjne, renty, ubezpieczenia na życie i inne, nieruchomości i aktywa osobiste, kredyty i pożyczki ${ }^{2}$. Jednym z najpopularniejszych sposobów opracowywania zestawień danych finansowych są sprawozdania finansowe, do których można zaliczyć bilans (balance sheet) i sprawozdanie z przepływów pieniężnych (cash flow). Ponadto w procesie zarządzania finansami osobistymi najczęściej wykorzystywanym narzędziem jest budżet domowy (household budget), będący jednocześnie zestawieniem pozyskanych dochodów i poniesionych wydatków w danym okresie oraz planów dotyczących przyszłego poziomu owych kategorii. W dobie rozwoju technologicznego pojawiło się wiele nowoczesnych narzędzi PFM (personal finance management tools) służących do konstruowania budżetu domowego.

Celem niniejszego artykułu jest określenie, $\mathrm{w}$ jakim stopniu polskie gospodarstwa domowe wykorzystują podstawowe narzędzia zarządzania finansami osobistymi. W opracowaniu zostaną scharakteryzowane wybrane narzędzia zarządzania finansami osobistymi oraz przedstawione wyniki badań pierwotnych dotyczących stosowania owych narzędzi w polskich gospodarstwach domowych.

* Uniwersytet Szczeciński, Wydział Zarządzania i Ekonomiki Usług.

1 Praca powstała w wyniku realizacji projektu badawczego nr 2013/09/N/HS4/03697 finansowanego ze środków Narodowego Centrum Nauki.

2 J.O. Lunney, L. Chambers, Strategie ochrony aktywów, Maksymalizacja zysku i kontrola ryzyka w niekorzystnych warunkach gospodarczych, Oficyna a Wolters Kluwer Business, Warszawa 2014, s. 210-212. 


\section{Wybrane instrumenty zarządzania finansami osobistymi}

Sprawozdaniem finansowym, które pozwala określić sytuację majątkową i źródła finansowania gospodarstwa domowego jest bilans. Podobnie jak w finansach przedsiębiorstw, bilans ma za zadanie ukazać sytuację majątkową gospodarstwa w danym momencie. Stanowi uporządkowany, sporządzony na konkretny moment dokument, zawierający zestawienie składników majątkowych i źródeł ich finansowania ${ }^{3}$. W bilansie zestawiamy stan aktywów i pasywów oraz wyliczamy wartość majątku. Aktywa to stan majątku danego gospodarstwa domowego, a pasywa - to źródła finansowania tegoż majątku. Bilans pokazuje nam źródła kapitału i sposób, w jaki kapitał jest inwestowany ${ }^{4}$. Za pomocą bilansu można analizować wzrost wartości aktywów i redukcję długów ${ }^{5}$. Podsumowując, bilans to sprawozdanie finansowe, które raportuje, co osoba lub rodzina posiada i jest winna w danym czasie.

Drugim narzędziem przydatnym $w$ dalszej analizie sytuacji finansowej gospodarstwa domowego, a także w zarządzaniu bieżącą płynnością gospodarstwa domowego jest zestawienie przepływów pieniężnych (cash flow). To fundamentalny instrument gospodarowania finansami osobistymi, który przedstawia listę wszystkich naszych dochodów i wydatków w danym okresie rozliczeniowym, np. w ciągu danego miesiąca lub roku' ${ }^{6}$ Sprawozdanie z przepływu środków pieniężnych pokazuje ${ }^{7}$ :

- czy dane gospodarstwo domowe wytwarza nadwyżkę finansową - kwotę, o jaką dochody przewyższają wydatki,

- czy wydatkuje cały dochód poprzez nadmierną, nieprzemyślaną konsumpcję, generując deficyt budżetowy - wydatki przewyższają dochody.

Sprawozdanie określa wielkość wygospodarowanej nadwyżki finansowej, która została zainkasowana konkretnie w danym okresie w formie wpływów pieniężnych, oraz przeznaczenie tych wpływów na określone cele ${ }^{8}$. Inaczej mówiąc, jest to raport rachunków i płatności za dany okres.

Trzecim, ostatnim, podstawowym narzędziem stosowanym przez gospodarstwo domowe jest budżet domowy, czyli plan dotyczący sposobu wydawania pieniędzy na nadchodzący miesiąc, miesiące czy dany rok. To zintegrowane sprawozdanie oparte na zestawieniu dochodów i wydatków. Budżet wyraża, co dana osoba chciałaby

3 Cz. Bywalec, Ekonomika i finanse gospodarstw domowych, PWN, Warszawa 2009, s. 34.

4 M. Lipiński, Organizowanie i planowanie własnych finansów, Quick, Gliwice 2009, s. 20.

5 L.J. Gitman, M.D. Joehnk, R.S. Billingsley, Personal financial planning, Cengage Learning, Mason 2014, s. 42 .

6 J.R. Kapoor, L.R. Dlabay, R.J. Hughes, Personal finance $8^{\text {th }}$, McGraw-Hill, New York 2007, s. 85.

L.J. Gitman, M.D. Joehnk, R.S. Billingsley, op.cit., s. 50.

8 M. Lipiński, op.cit., s. 20. 
osiągnąć w sferze wydawania i oszczędzania w przyszłości. Budżet gospodarstwa domowego to narzędzie, które pozwala określić wysokość wydatków w danym tygodniu, miesiącu lub roku oraz wysokość planowanych oszczędności. Tworzenie budżetu pozwala określić ilość pieniędzy, jaka znajduje się w posiadaniu danego gospodarstwa domowego, jak również ich przeznaczenie. Pozwala na kontrolowanie wydatków i zapobieganie niewypłacalności. Budżet może być również pomocnym narzędziem do osiągnięcia specjalnych oszczędności w celu zakupu nowego komputera czy samochodu ${ }^{10}$, czyli wyznaczonych celów finansowych. W budżecie domowym, podobnie jak w zestawieniu dochodów i wydatków, istotną rolę odgrywają źródła i rodzaje dochodów oraz struktura wydatków. Budżet zrównoważony to taki, w którym strona dochodów równa się stronie wydatków ${ }^{11}$.

Przyjęty w Polsce miesięczny cykl pobierania wynagrodzeń i świadczeń oraz dokonywania płatności powoduje, że budżet domowy tworzony jest zazwyczaj raz na miesiąc. $Z$ powodu wydatków, które pojawiają się rzadziej niż raz w miesiącu (np. ubezpieczenia czy podróże) wynika potrzeba tworzenia budżetu domowego w ujęciu rocznym. Budżet roczny ułatwia planowanie budżetów miesięcznych ${ }^{12}$. Ponadto budżet powinien być13:

- dobrze zaplanowany - przygotowanie dobrego budżetu zajmuje czas i wymaga wysiłku, każdy domownik powinien być zaangażowany w tę czynność,

- realistyczny - jeśli przychód nie jest wysoki, nie należy oczekiwać, że zaoszczędzi się na luksusowy samochód,

- elastyczny - nieoczekiwane wydarzenia i sytuacja rynkowa powodują zmiany w budżecie,

- klarownie komunikowany - wszyscy domownicy powinni znać plan wydatków. Proces tworzenia budżetu domowego składa się z kilku etapów ${ }^{14}$ :

- określenia celów finansowych,

- oszacowania dochodów,

- prognozowania wysokości oszczędności i funduszy na niespodziewane wydatki,

- prognozowania wydatków stałych i zmiennych,

- kontrola zaplanowanych dochodów i wydatków.

\footnotetext{
9 E. Faerber, The personal finance calculator: how to calculate the most important financial decisions in your life, The McGraw-Hill Comp., USA 2003, s. 12.

${ }^{10}$ H. Hammonds, Budgeting, Smart Apple Media, USA 2006, s. 4.

${ }^{11}$ K.P. Łabenda, Budżet domowy pod kontrola - jak rozsąnie wydawać, oszczędzać i inwestować pieniqdze, Helion, Gliwice 2011, s. 44.

12 J. Mierzejewska-Majcherek, Podstawy ekonomii, Difin, Warszawa 2003, s. 132133.

13 J.R. Kapoor, L.R. Dlabay, R.J. Hughes, op.cit., s. 51.

${ }^{14}$ Ibidem, s. 89.
} 
Cele finansowe określane są na podstawie dwóch wytycznych: ram czasowych, w których mają one zostać osiągnięte i potrzeb członków gospodarstwa domowego.

Kiedy cele finansowe zostaną wyznaczone, należy ustalić wysokość dochodów ze wszystkich źródeł, określić wysokość funduszy na tzw. „czarną godzinę” oraz oszczędności, zaplanować wydatki stałe i zmienne na kolejne okresy rozliczeniowe na podstawie wcześniejszych zestawień dochodów i wydatków. Następnie warto przygotować plan kontroli budżetu (budget control schedule), tzn. comiesięczne podsumowanie, jakie dochody zostały pozyskane i jakie wydatki poniesione przez gospodarstwo domowe, porównać je z planami budżetowymi i zaobserwować różnice ${ }^{15}$.

W literaturze wymienia się cztery sposoby monitorowania i gospodarowania finansami osobistymi (personal finance management - PFM tools) ${ }^{16}$ :

- Paper and pen - monitorowanie finansów osobistych za pomocą papieru i długopisu - „ręcznie”,

- Desktop PFM - gospodarowanie finansami osobistymi przy użyciu arkuszy kalkulacyjnych (np. Excela), oprogramowania finansowego typu: Quicken czy Intuit. Polega ono na importowaniu danych w formie plików csv z instytucji finansowych i tworzeniu w komputerze własnej bazy transakcji,

- Online PFM - korzystanie z narzędzi gospodarowania finansami osobistymi oferowanych w ramach kont internetowych, tzn. klient logując się do swojego konta i wykorzystując podstawowe funkcje dostarczane w ramach rachunku bankowego, może sprawdzić saldo, zadłużenie czy harmonogram spłat,

- Web PFM - gospodarowanie finansami osobistymi za pośrednictwem zewnętrznych platform internetowych, $\mathrm{z}$ wykorzystaniem operacji finansowych w jednym miejscu (np. www.kontomierz.pl czy www.domowybudżet.pl).

\section{Metodyka badawcza}

Badania przeprowadzone zostały w trzech wybranych województwach: zachodniopomorskim, dolnośląskim i podkarpackim. Wyboru województw dokonano na podstawie wskaźników określających dochody, wydatki oraz dobrobyt materialny mieszkańców danego województwa (tabela 1). Województwo dolnośląskie charakteryzuje się wysokimi wskaźnikami: przeciętnych miesięcznych dochodów

${ }^{15}$ L.J. Gitman, M.D. Joehnk, R.S. Billingsley, op.cit., s. 65.

16 A. Barembruch, Bankowość detaliczna a nowoczesne narzędzia wspomagające zarzadzanie finansami osobistymi, „Prace i Materiały Wydziału Zarządzania Uniwersytetu Gdańskiego” 2013, nr 2/1, s. 37-38. 
rozporządzalnych na osobę w gospodarstwie domowym, przeciętnych miesięcznych wydatków na osobę w gospodarstwie domowym oraz wskaźnikiem dobrobytu materialnego ${ }^{17}$. Z drugiej strony wybrano województwo podkarpackie, charakteryzujące się najniższymi omawianymi wskaźnikami określającymi finanse osobiste mieszkańców Polski. Trzecim województwem jest zachodniopomorskie, które charakteryzuje się przeciętnymi wynikami owych wskaźników.

Tabela 1. Charakterystyka województw Polski pod względem dochodów, wydatków i dobrobytu materialnego

\begin{tabular}{|l|c|c|c|}
\hline \multicolumn{1}{|c|}{ Województwo } & Dochody $(\mathrm{w} \%)^{\star}$ & Wydatki $(\mathrm{w} \%)^{\star *}$ & Dobrobyt materialny*** $^{\star *}$ \\
\hline dolnośląskie & $\mathbf{1 0 6 , 9 0}$ & $\mathbf{1 0 7 , 6 0}$ & $\mathbf{0 , 0 4}$ \\
\hline kujawsko-pomorskie & 88,70 & 89,60 & $-0,19$ \\
\hline lubelskie & 82,60 & 87,40 & $-0,22$ \\
\hline lubuskie & 96,30 & 95,80 & $-0,01$ \\
\hline tódzkie & 99,20 & 103,10 & $-0,11$ \\
\hline małopolskie & 93,10 & 94,30 & 0,06 \\
\hline mazowieckie & 133,80 & 128,80 & 0,17 \\
\hline opolskie & 101,20 & 101,70 & $-0,03$ \\
\hline podkarpackie & $\mathbf{7 5 , 0 0}$ & $\mathbf{8 0 , 2 0}$ & $-\mathbf{0 , 2 2}$ \\
\hline podlaskie & 97,20 & 89,60 & 0,02 \\
\hline pomorskie & 105,60 & 101,70 & 0,05 \\
\hline śląskie & 100,00 & 104,80 & 0,02 \\
\hline świętokrzyskie & 87,60 & 83,30 & $-0,32$ \\
\hline warmińsko-mazurskie & 86,80 & 83,50 & $-0,11$ \\
\hline wielkopolskie & 90,20 & 88,40 & $-0,04$ \\
\hline zachodniopomorskie & $\mathbf{9 8 , 8 0}$ & $\mathbf{9 8 , 4 0}$ & $\mathbf{0 , 0 6}$ \\
\hline
\end{tabular}

* Wskaźnik przeciętnego miesięcznego dochodu rozporządzalnego na osobę w gospodarstwie domowym w stosunku do średniej krajowej w $2012 \mathrm{r}$.

** Wskaźnik przeciętnych miesięcznych wydatków na osobę w gospodarstwie domowym w stosunku do średniej krajowej w $2012 \mathrm{r}$.

*** Wskaźnik dobrobytu materialnego obliczany jest na podstawie dochodu gospodarstwa domowego na jednostkę ekwiwalentną, liczby posiadanych przez gospodarstwo domowe dóbr i urządzeń od pralki automatycznej po łódź motorową i dom letniskowy (z wyłączeniem urządzeń wchodzących w skład wskaźnika poziomu cywilizacyjnego, tj. laptop, komputer, telefon komórkowy).

Źródło: Sytuacja gospodarstw domowych w $2012 \mathrm{r}$. w świetle wyników badań budżetów gospodarstw domowych, GUS, http://www.stat.gov.pl/gus/5840_1160_PLK_HTML.htm, dostęp 26.10.2013; Diagnoza społeczna 2013, red. J. Czapiński, T. Panek, Warszawa 2013, s. 379, www.diagnoza.com, dostęp 26.10.2013.

17 Diagnoza społeczna 2013, red. J. Czapiński, T. Panek, Warszawa 2013, s. 379, www.diagnoza.com, dostęp 26.10.2013. 
Przyjmując dopuszczalny błąd na poziomie 5\%, w każdym z wybranych województw przebadano 384 podmioty, co w efekcie końcowym daje liczebność próby dla trzech wybranych województw wynoszącą 1152 badane podmioty.

Badania zostały przeprowadzone przy pomocy elektronicznego kwestionariusza ankiety $\left(\mathrm{CAWI}^{18}\right)$ oraz papierowego kwestionariusza ankiety $\left(\mathrm{PAPI}^{19}\right)$. Przy ankiecie bezpośredniej w badaniu pilotażowym zastosowano metodę doboru nielosowego, dobór jednostek typowych ${ }^{20}$, w celu przetestowania kwestionariusza. Próba do badań bezpośrednich wylosowana została przy zastosowaniu metody losowania warstwowego. Sposobem doboru respondentów w wypadku ankiety internetowej będzie metoda doboru werbunkowego, w postaci paneli dobrowolnych ${ }^{21}$.

\section{Wyniki}

Na podstawie przeprowadzonych badań ankietowych zbadano stosowanie wybranych instrumentów w polskich gospodarstwach domowych: tworzenie budżetu domowego, cash flow, bilansu oraz planów finansowych, rozumiane jako zestawienie posiadanego majątku, celów finansowych, budżetu domowego, planu emerytalnego oraz ubezpieczeniowego.

Spośród badanych osób tylko niecałe 30\% tworzy sprawozdanie z przepływu środków pieniężnych (cash flow), ok. 13\% tworzy bilans gospodarstwa domowego, 18\% tworzy plany finansowe, natomiast aż $82 \%$ respondentów tworzy budżet domowy, choć robi to $\mathrm{z}$ różną częstotliwością (21\% badanych osób tworzy budżet domowy raz w miesiącu).

Ponadto zapytano respondentów o sposób zapisywania wydatków i dochodów gospodarstwa domowego: 23\% wskazało, iż korzysta z notatnika, niecałe 9\% z Excella, a $4 \%$ ze specjalnego programu komputerowego. Dodatkowo niecałe $9 \%$ respondentów posiada konto osobiste z programem do zarządzania budżetem domowym. Wśród stosowanych programów komputerowych i kont osobistych ze specjalnym oprogramowaniem respondenci wymieniali: AceMoney Lite 4.35.2, domowe finanse, konto ING, konto PKO BP, konto mBanku, konto Alior Sync oraz aplikacje ICO.

\footnotetext{
18 Ankieta CAWI (Computer-Assisted Web Interview) - badanie przeprowadzane za pośrednictwem Internetu.

19 Ankieta PAPI (Paper \& Pencil Interview) - ankieta papierowa.

20 S. Kaczmarczyk, Badania marketingowe. Podstawy metodyczne, PWE, Warszawa 2011, s. 98.

${ }^{21}$ Ibidem, s. 100.
} 
W celu przeanalizowania zależności pomiędzy stosowaniem poszczególnych narzędzi zarządzania finansami gospodarstw domowych a wybranymi cechami respondentów, tj. płeć, wiek, wykształcenie, liczba osób w gospodarstwie domowym, zamieszkiwany obszar, a także czynnikami ekonomicznymi, tj. miesięczny dochód gospodarstwa domowego, wydatki ogółem gospodarstwa domowego, wydatki na pokrycie zadłużenia czy miesięczne oszczędności, wyznaczono współczynniki korelacji pomiędzy badanymi zmiennymi, które zostały zaprezentowane w tabeli 2.

Dwie spośród badanych zmiennych: wiek i miesięczne wydatki ogółem gospodarstwa domowego nie korelują istotnie statystycznie $(\mathrm{p}>0,05)$ ze zmiennymi dotyczącymi stosowania poszczególnych narzędzi.

Tabela 2. Zależność pomiędzy wybranymi cechami społeczno-ekonomicznymi a stosowaniem wybranych narzędzi zarządzania finansami osobistymi

\begin{tabular}{|c|c|c|c|c|}
\hline Zmienne & Cash flow & Budżet domowy & Bilans & Plan finansowy \\
\hline Płeć & $\begin{array}{c}0,0748 \\
(p=0,012)\end{array}$ & $\begin{array}{c}-0,0398 \\
(p=0,180)\end{array}$ & $\begin{array}{c}0,0183 \\
(p=0,536)\end{array}$ & $\begin{array}{c}0,0330 \\
(p=0,266)\end{array}$ \\
\hline Wiek & $\begin{array}{c}0,0483 \\
(p=0,100)\end{array}$ & $\begin{array}{c}-0,0154 \\
(p=0,601)\end{array}$ & $\begin{array}{c}0,0492 \\
(p=0,094)\end{array}$ & $\begin{array}{c}0,0392 \\
(p=0,183)\end{array}$ \\
\hline Wykształcenie & $\begin{array}{l}0,1659 \\
(0,000) \\
\end{array}$ & $\begin{array}{l}0,1244 \\
(0,000) \\
\end{array}$ & $\begin{array}{l}0,0862 \\
(0,003) \\
\end{array}$ & $\begin{array}{c}0,1531 \\
(p=0,000)\end{array}$ \\
\hline Liczba osób w gd & $\begin{array}{c}-0,0275 \\
(p=0,362)\end{array}$ & $\begin{array}{c}0,0384 \\
(p=0,203)\end{array}$ & $\begin{array}{c}0,0833 \\
(p=0,006)\end{array}$ & $\begin{array}{c}0,0704 \\
(p=0,019)\end{array}$ \\
\hline Zamieszkiwany obszar & $\begin{array}{c}0,0263 \\
(p=0,385)\end{array}$ & $\begin{array}{c}0,0418 \\
(p=0,168)\end{array}$ & $\begin{array}{c}0,0092 \\
(p=0,762)\end{array}$ & $\begin{array}{c}0,0101 \\
(p=0,739)\end{array}$ \\
\hline Dochód (miesięczny) & $\begin{array}{c}0,0268 \\
(p=0,365)\end{array}$ & $\begin{array}{c}0,0527 \\
(p=0,075)\end{array}$ & $\begin{array}{c}0,1068 \\
(p=0,000)\end{array}$ & $\begin{array}{l}0,0270 \\
(0,361) \\
\end{array}$ \\
\hline Wydatki (miesięczne) & $\begin{array}{c}-0,0238 \\
(p=0,517)\end{array}$ & $\begin{array}{l}0,0693 \\
(0,060) \\
\end{array}$ & $\begin{array}{c}0,0511 \\
(p=0,165)\end{array}$ & $\begin{array}{c}0,0608 \\
(p=0,098)\end{array}$ \\
\hline Zadłużenie (miesięczne) & $\begin{array}{c}0,0748 \\
(p=0,050)\end{array}$ & $\begin{array}{c}0,0426 \\
(p=0,264)\end{array}$ & $\begin{array}{l}0,1782 \\
(0,000) \\
\end{array}$ & $\begin{array}{l}\mathbf{0 , 0 8 0 4} \\
(\mathbf{0}, 035) \\
\end{array}$ \\
\hline Oszczędności (miesięczne) & $\begin{array}{c}0,0549 \\
(p=0,170)\end{array}$ & $\begin{array}{l}0,0283 \\
(0,479)\end{array}$ & $\begin{array}{c}0,0111 \\
(p=0,781)\end{array}$ & $\begin{array}{c}0,0788 \\
(p=0,049)\end{array}$ \\
\hline
\end{tabular}

Źródło: Opracowanie własne.

Interesująca może wydawać się korelacja poziomu wykształcenia ze wszystkimi czterema narzędziami, co oznacza, że wraz ze wzrostem wykształcenia zwiększa się liczba osób stosujących wszystkie cztery narzędzia: cash flow, bilans, budżet domowy i plan finansowy.

W celu przeanalizowania stosowania narzędzi zarządzania finansami gospodarstw domowych, badaną populację podzielono na pięć grup. Respondenci otrzymali punkty za stosowanie poszczególnych narzędzi gospodarowania finansami osobistymi: budżetu domowego, cash flow, bilansu, planu finansowego. Osoba, która 
nie stosuje żadnego z wymienionych narzędzi, otrzymała 0 punktów, a osoba, która korzysta ze wszystkich - 4 punkty. W badanej populacji 13\% osób nie korzysta z żadnych z wymienionych narzędzi gospodarowania finansami osobistymi, podczas gdy niespełna 5\% korzysta ze wszystkich czterech. Prawie połowa osób korzysta tylko $\mathrm{z}$ jednego $\mathrm{z}$ wymienionych narzędzi.

W grupie osób, które nie stosują żadnych narzędzi zarządzania finansami osobistymi dominują kobiety, osoby w wieku 25-33, o średnim wykształceniu, mieszkające na wsi, o miesięcznym dochodzie 3246 PLN i wydatkach ok. 1934 PLN, które miesięcznie oszczędzają ok. 447 PLN i przeznaczają ok. 165 PLN na spłatę zadłużenia. Natomiast w grupie osób, które korzystają ze wszystkich czterech narzędzi zarządzania finansami osobistymi znalazło się tyle samo kobiet co mężczyzn, przeważają osoby w wieku 34-49, o wyższym wykształceniu (magisterskim), mieszkające w mieście (od 100 do 500 tys. mieszkańców), o średnim miesięcznym dochodzie ok. 4676 PLN i wydatkach na poziomie ok. 2605 PLN, które oszczędzają miesięcznie ok. 2000 PLN i przeznaczają ok. 500 PLN na spłatę zadłużenia.

\section{Dyskusja}

Najpopularniejszym z przedstawionych narzędzi zarządzania finansami osobistymi jest budżet domowy. Wykorzystywanie budżetu domowego przez polskie gospodarstwa domowe do kontrolowania swoich dochodów i wydatków jest tematem wielu badań w przeciwieństwie do badań dotyczących wykorzystywania bilansu czy planów finansowych przez gospodarstwa domowe. W większości badań brakuje również rozróżnienia na cash flow i budżet domowy, co powoduje, iż osoby, które jedynie zapisują dochody i wydatki, bez planowania i kontrolowania ich poziomu, są traktowane w badaniach tak samo jak osoby, które planują i kontrolują wydatki i dochody.

Jedne z ostatnich badań dotyczących wykorzystywania budżetu domowego przez polskie gospodarstwa domowe przeprowadzono w marcu $2014 \mathrm{r}$. w serwisie Interia. $\mathrm{p}^{122}$. Według nich 61\% Polaków zarządza budżetem domowym. Wśród respondentów, którzy zadeklarowali, że zarządzają budżetem domowym, najwięcej osób (69\%) wykorzystuje do tego kartkę, długopis i ewentualnie kalkulator. Jedną czwartą stanowiły osoby, które w komputerze zapisują wydatki i wpływy finansowe gospodarstwa

\footnotetext{
$22 \mathrm{http} / / /$ mojafirma.infor.pl/budzet-domowy/oszczedzanie/304664, Jak-Polacy-kontroluja-budzet-domowy.html, dostęp 12.03.2015.
} 
domowego. Tylko 7\% zadeklarowało korzystanie ze specjalistycznych narzędzi PFM, tj. finansometra ING Banku Śląskiego czy Asystenta finansowego Banku BPH.

W omawianym badaniu nie wykazano, aby to mężczyźni czy kobiety częściej wskazywali na stosowanie budżetu domowego. Natomiast kobiety częściej ograniczają się do odręcznych notatek, a mężczyźni chętniej korzystają z narzędzi wymagających użycia komputera. Interesujący wydaje się fakt, iż w omawianych badaniach największy odsetek deklarujących stosowanie budżetu domowego stanowi grupa osób po 54. roku życia (64\%) i w wieku 25-34 (63\%).

Ponadto, według badań przeprowadzonych na zlecenie Fundacji Narodowego Dnia Życia w ramach programu Rodzina receptą na kryzys ${ }^{23}$, rodziny z dziećmi częściej planują swój budżet domowy. Według tego badania, aż 33\% Polaków w ogóle nie planuje budżetu domowego, $34 \%$ planuje go na bieżąco, $2 \%$ na początku tygodnia, a $9 \%$ przed większymi wydatkami.

\section{Podsumowanie}

Polskie gospodarstwa domowe w małym zakresie stosują narzędzia gospodarowania finansami osobistymi. Najpopularniejszym narzędziem jest budżet domowy, który większość Polaków sporządza w sposób tradycyjny, czyli za pomocą kartki i długopisu. Niewielu, bo niecałe 10\%, Polaków (według różnych badań) korzysta ze specjalistycznego oprogramowania do zarządzania finansami osobistymi, co $\mathrm{w}$ dobie społeczeństwa informacyjnego jest raczej niewielkim odsetkiem w opinii autorki. Warto dodać, iż udało się wykazać zależność pomiędzy stosowaniem narzędzi zarządzania finansami osobistymi i wykształceniem, tzn. odsetek osób stosujących narzędzia gospodarowania finansami osobistymi wzrasta wraz ze wzrostem poziomu wykształcenia. Nie wykazano natomiast zależności pomiędzy płcią oraz wiekiem a stosowaniem omawianych narzędzi.

\footnotetext{
${ }^{23} \mathrm{http}$ //wiadomosci.wp.pl/kat,1342, title,Wiekszosc-Polakow-nie-planuje-budzetu-domowego,wid, 14995052, wiadomosc.html?ticaid=1147e6, dostęp 12.03.2015.
} 


\section{Bibliografia}

Barembruch A., Bankowość detaliczna a nowoczesne narzędzia wspomagające zarządzanie finansami osobistymi, „Prace i Materiały Wydziału Zarządzania Uniwersytetu Gdańskiego" 2013, nr 2/1.

Bywalec Cz., Ekonomika i finanse gospodarstw domowych, PWN, Warszawa 2009.

Diagnoza społeczna 2013, red. J. Czapiński, T. Panek, Warszawa 2013, www.diagnoza.com, dostęp 26.10.2013.

Faerber E., The personal finance calculator: how to calculate the most important financial decisions in your life, The McGraw-Hill Comp., USA 2003.

Gitman L.J., Joehnk M.D., Billingsley R.S., Personal financial planning, Cengage Learning, Mason 2014.

Hammonds H., Budgeting, Smart Apple Media, USA 2006.

http://mojafirma.infor.pl/budzet-domowy/oszczedzanie/304664, Jak-Polacy-kontroluja-budzet-domowy.html, dostęp 12.03.2015.

http://wiadomosci.wp.pl/kat,1342, title,Wiekszosc-Polakow-nie-planuje-budzetudomowego,wid,14995052, wiadomosc.html?ticaid=1147e6, dostęp 12.03.2015.

Kaczmarczyk S., Badania marketingowe. Podstawy metodyczne, PWE, Warszawa 2011.

Kapoor J.R., Dlabay L.R., Hughes R.J., Personal finance $8^{\text {th }}$, McGraw-Hill, New York 2007.

Lipiński M., Organizowanie i planowanie własnych finansów, Quick, Gliwice 2009.

Lunney J.O., Chambers L., Strategie ochrony aktywów, Maksymalizacja zysku i kontrola ryzyka w niekorzystnych warunkach gospodarczych, Oficyna a Wolters Kluwer Business, Warszawa 2014.

Łabenda K.P., Budżet domowy pod kontrola - jak rozsądnie wydawać, oszczędzać i inwestować pieniądze, Helion, Gliwice 2011.

Mierzejewska-Majcherek J., Podstawy ekonomii, Difin, Warszawa 2003.

\section{Application of Personal Finance Management Tools by Polish Households}

One of the most important elements of managing personal finances is collection of data needed for the analysis of household's financial situation. The most popular personal finance management tools include financial statements (balance sheets and cash flows) and household budget. The purpose of this article is to determine how Polish households use the basic personal finances management 
tools. The article will characterize the tools and present the results of primary studies concerning the use of these tools by Polish households.

Keywords: household budget, PFM, household finance

\section{L'application des outils de gestion des finances personnelles par les ménages polonais}

L'un des éléments les plus importants de la gestion des finances personnelles est la collecte des données nécessaires pour analyser la situation financière des ménages. Les outils les plus populaires de la gestion des finances personnelles comprennent les états financiers (bilans et flux de trésorerie) et le budget des ménages. Le but de cet article est de déterminer comment les ménages polonais utilisent les outils de gestion des finances personnelles. L'article caractérise ces outils et présente les résultats des études primaires concernant l'utilisation de ces outils par les ménages polonais.

Mots-clés: le budget des ménages, la gestion des finances personnelles, les finances des ménages

\section{Использование инструментов управления личными финансами в польских домохозяйствах}

Одним из самых важных элементов управления личными финансами является сбор данных, необходимых для анализа финансового положения домохозяйства. Наиболее популярные инструменты управления личными финансами включают в себя: финансовую отчетность - баланс и отчет о движении денежных потоков, и бюджет домохозяйства. Цель статьи - изучить в какой степени польские домохозяйства пользуются основными инструментами управления личными финансами. В статье приводится характеристика инструментов и представлены результаты первичных исследований относительно их использования в польских домохозяйствах.

Ключевые слова: бюджет домохозяйства, PFM, финансы домохозяйств 
